\title{
GOODBYE BOAR, HELLO RAT!
}

\author{
Toshio Ohshiro MD PhD
}

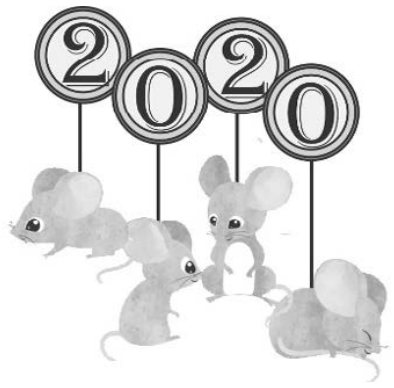

SO, GOODBYE TO THE YEAR OF THE BOAR, and hello to the Year of the Metal (or Gold) Rat (January $25^{\text {th }}, 2020$-February $4^{\text {th }}$, 2021). Although not so many people can be said to love and cherish rats, the rat is the first animal in the Oriental 12-animal Zodiac.

Legend has it that the Jade Emperor (one of the representations of the First God) was having a party, and invited the animals to come but challenged them to a race to decide their order in the zodiac. Rat tricked Ox into giving him a ride, but just before the finishing line, with $\mathrm{Ox}$ ahead of the rest, Rat jumped off and scampered over the line first: hence the Jade Emperor made him the first animal in the Zodiac (which is Rat, Ox, Tiger, Rabbit, Dragon, Snake, Horse, Goat, Monkey, Rooster, Dog and Boar). If you were born in 1912, 1924, 1936, 1948, 1960, 1972, 1884, 1996 or 2008, then you are a Rat. However, Rats are valued animals in the Zodiac. Rats are optimistic and energetic, sensitive to other's emotions but tend to be stubborn regarding their own opinion. They are kind, but tend to appear a bit brusque due to poor interpersonal skills. Loving money, they tend to be stingy but will occasionally splurge on unnecessary objects. If 2020 is your year, welcome!

\section{Climate Change is "False News" ... Really?}

It is well-recognized that Japan sits on the on the socalled volcanic "Ring of Fire" where the major Asian-Pacific tectonic plates grumble, groan and bang alongside, off and onto each other, resulting in earthquakes. In any one-week period, at least 2 small but recognizable quakes are more or less guaranteed. But it wasn't quakes that caused the problems in the last quarter of this year: it was typhoons (typhoons in Asia, hurricanes elsewhere in the northern hemisphere, and cyclones in the Southern Hemisphere ... trivia time). In addition to being on the Ring of Fire, Japan is also in "Typhoon Alley", fortunately, at the edge (the Philippines are slap in the middle). However, it was Japan that recently took the brunt of not one, not two but three "super typhoons".

Although typhoons and tropical storms are named, in Japan they traditionally been numbered. Typhoon No 19 (Faxai) hit in early September and wrought havoc in south west Japan, No 24 (Hagibis) hit in mid-October (disrupting three Rugby World Cup matches in the process), and No 26 (Bualoi) hit the east of Japan the week after Hagibis had flooded huge areas, displaced thousands from their homes and killed over 100. Although Bualoi's path was many kilometers out into the Pacific, the outrider winds still reached over $100 \mathrm{~km} / \mathrm{h}$ with more torrential rain, more flooding and more than 30 deaths. As I write, the clean-up operations are still going on with many large car parks in the affected areas filled with acres of damaged and destroyed household electrical and soft goods which will have somehow to be disposed of. Our thoughts are with those families who have lost loved ones, and those whose homes were inundated and have been left virtually homeless.

In fact, with the season still in progress (No 33 is at the time of writing working its way up from the Philippines) the 2019 typhoon season has been the second costliest ever in terms of loss of life and damage-related costs. I also have to say that not only Japan has been affected, but flooding has caused havoc also in Europe, with 3 months' rain falling in 2 days in places in the UK, and winter storms, so called "bomb cyclones", ravaging the US over the Thanksgiving period. So, climate change is a myth, is it? Don't mess with nature!

\section{Laser Therapy Tightens our Belt}

After 28 volumes over 30 years of providing our publishing services for authors without any page charges, I am really sorry to say that commercial and economic reality has forced Laser Therapy to change our free publication policy. From Volume 29 issue 1 onwards we have been forced with regret to levy a publication charge. Upon acceptance of their paper, authors will have to pay a flat charge of US $\$ 300$ prior to publication. I appreciate this is a sudden increase, but it is in line with the other major journals. To help offset that, I have decided to scrap colour printing charges, so a reasonable number of colour illustrations will be included in that $\$ 300$ charge. I 
thought long and hard about this, and up till now I have managed to resist suggestion from our accounting team, but rising costs across the board, including the recent hike in value-added tax (consumption tax) here in Japan, have forced me to accede to their demands.

I understand that some authors are keen to have their papers published early as ePublications ahead of print. The charge for that has now increased to US $\$ 200$, which will be in addition to the flat rate page charge of $\$ 300$ mentioned above. These changes will be echoed in the "Notes for Contributors" from the current issue, and will take effect immediately for all papers appearing in Volume 29:1 and thereafter. Once again I apologize for these charges, but the reality is that we could not continue to publish in the current economic climate without following the other major publications' lead regarding page charges.

\section{Editorial Board Update}

The Editorial Team recently lost our long-standing Editorial Coordinator, but I am happy to say that we welcome an excellent replacement in the person of Dr Reiko Sakio. Dr Sakio is a plastic surgeon, and is on the staff of the Ohshiro Clinic. She is currently a Resident at the Department of Plastic and Reconstructive Surgery, Keio University School of Medicine, with her postgraduate work carried out at Kyorin University, School of Medicine. She has kindly agreed to extend her services to assist with the Editorial Team tasks which will make a big difference to the workload! Dr Sakio will also join the International Editorial Board and will act as a reviewer for appropriate papers. Also, please welcome Dr Haruhiko Kosuge, a dermatologist currently working at The Department of Dermatology, Hino Municipal Hospital in Tokyo. Dr Ko- suge will also be assisting us as a Member of the Editorial Board and a member of the review panel.

\section{Laser Therapy Octogenarians' Society (LTOS)}

Dear readers, As many of our faithful Laser Therapy supporters from its inception in 1988 will have noticed, tempus REALLY fugit! To me it seems like no time at all since we had the happy news from the Chichester UK HQ of John Wiley and Sons that not only had they successfully published Low Level Laser Therapy: A Practical Introduction by my self and R Glen Calderhead, the first book dedicated to LLLT, they had also put together the Pilot Issue of this very journal, both of which were displayed on the John Wiley stand at the British Medical Laser Association's meeting in Manchester of that year. That is, unbelievably or not, 31 years ago, so even young whippersnappers in their 30s at that time will now be in their 60s, and those of us who were just a little older have reached their allotted "three score years and ten" (The Bible, Psalm 90:10), whereas others have exceeded that to reach their $80^{\text {th }}$ birthday (which would be "four score years and ten" by that somewhat archaic counting method). For readers who are a little puzzled by this usage of the word 'score', it is an older term meaning 20, although you've probably worked that out! Well, in this New Millennium age, it is certainly not uncommon to reach one's 70 s any more, thanks to lifestyle and environmental improvements. But I think to reach one's 80 s is still a good milestone and so I have unilaterally founded the Laser Therapy Octogenarians' Society. To initiate the LTOS, it gives me great pleasure to welcome one of our LLLT stalwarts as a member, none other than Professor Mary Dyson! So, on behalf of all of us who know her well, may I wish her the happiest of birthdays on the occasion of her $80^{\text {th }}$ ! Here she is look-

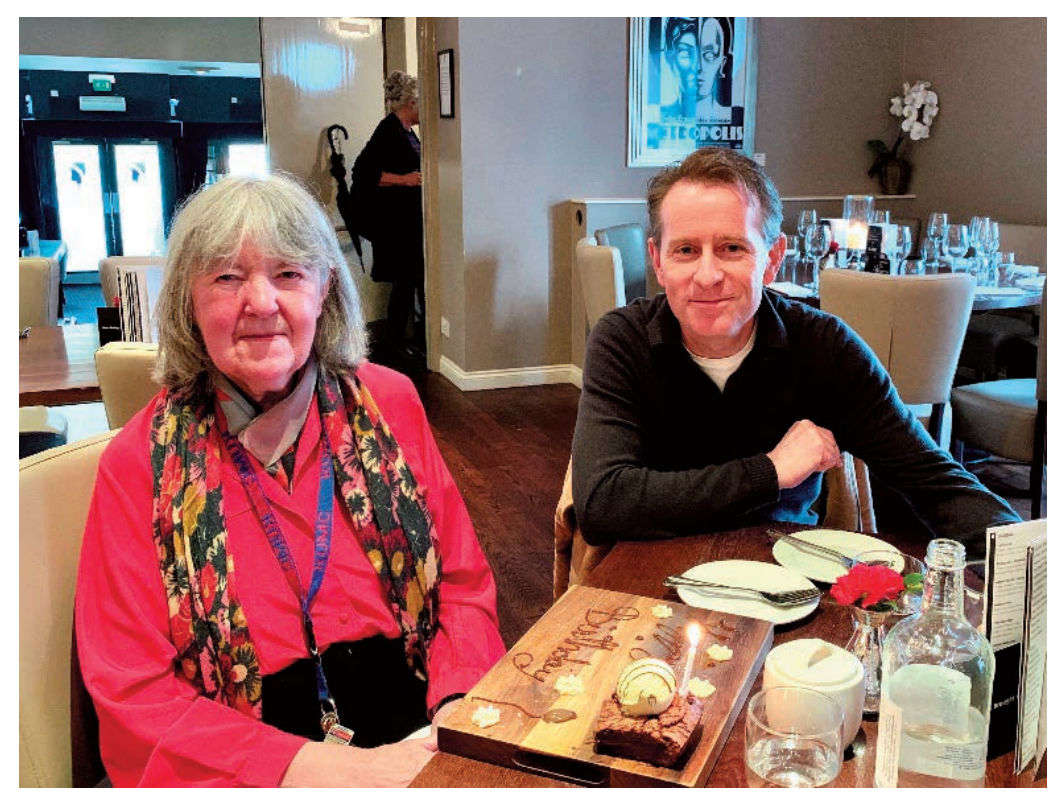



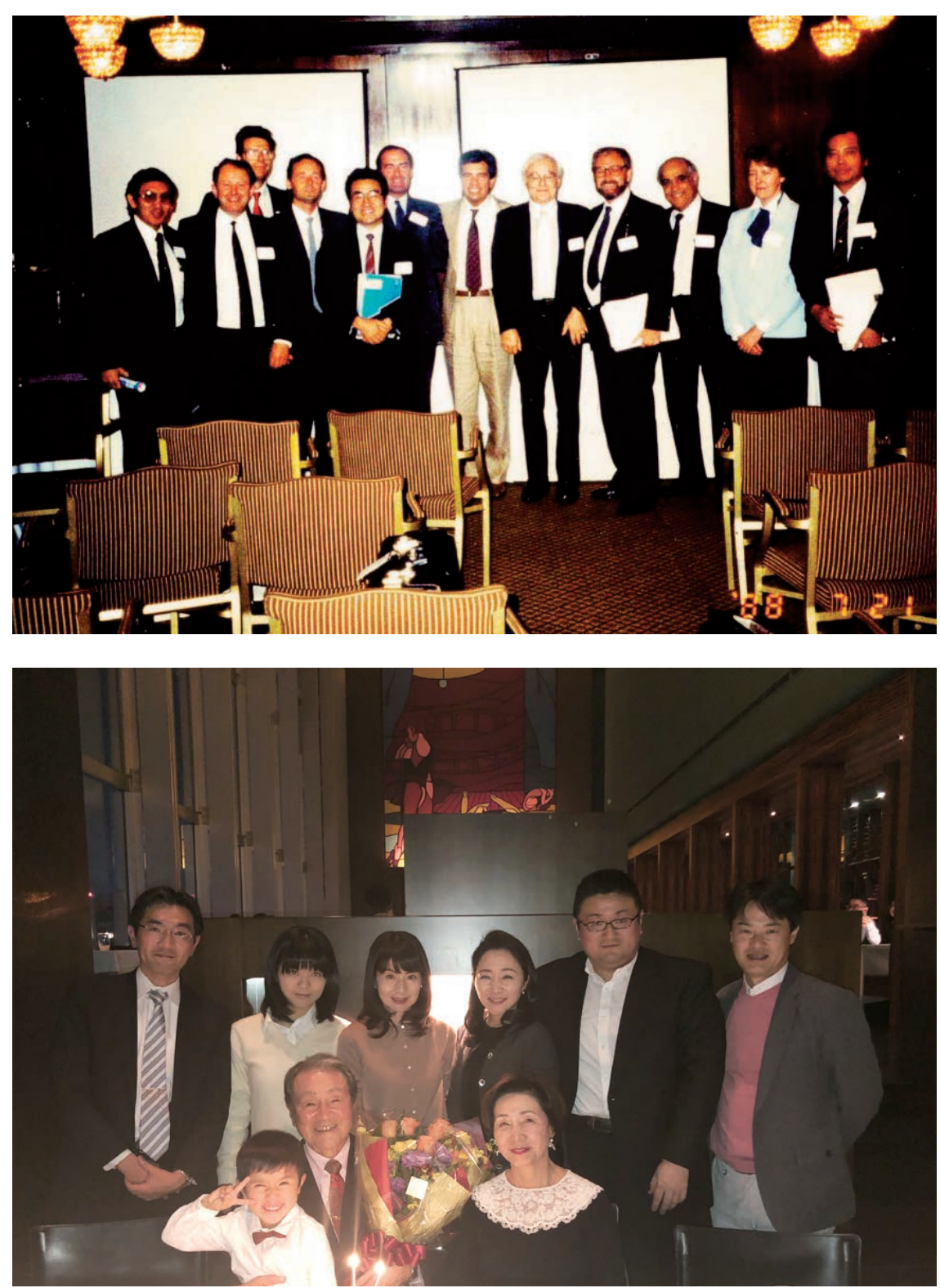

ing great at her octogenarian celebration lunch with James Carroll of Thor Lasers: James is another long-term proponent and researcher in the photobiomodulation field.

Dr Dyson is one of the leaders in the field of tissue repair and wound healing, and is one of my dear friends and a most respected colleague. In the anatomy and wound healing arena, Dr Dyson is recognised as one of the Co-Editors of the $37^{\text {th }}$ and $38^{\text {th }}$ editions of the Anatomical Bible, "Gray's Anatomy". Mary very swiftly took up the challenge of LLLT when the third "L" was still laser, and was one of the brave band of pioneers who formed the International Laser Therapy Association (ILTA) in our inaugural foundation meeting in London, July 1988, and here she is with myself and the others who formed that first step towards the recognition of LLLT by a formal organisation, from which WALT evolved.

Founding meeting of the International Laser Therapy Association, (ILTA), London Hilton, July 1988: From left: the late Prof Peter Hasan, Prof Kevin Moore, Dr Adam Mester, Prof Kenichiro Inomata, Prof Toshio Ohshiro, Prof John Carruth, Prof Mario Trelles, Dr Robert Scott, Dr R Glen Calderhead, the late Prof Naru Hira, Prof Mary Dyson, and Prof Ming-Chien Kao.

Dr Dyson served on the ILTA Executive Committee first as Treasurer from the Okinawa inaugural meeting in 1990, then as President at the Laser London 1992 meeting and continued on as a Committee Member when ILTA became the World Association for Laser Therapy (WALT) in 1994 in Barcelona, Spain. Dr Dyson served as the UK liaison for the International Phototherapy Association (IPTA) from its inception, and has been a staunch International Editorial Board Member for many years. We wish her many more happy years!

In the last issue you will remember we mentioned the $80^{\text {th }}$ birthday of another LLLT pioneer, Mr Felix Kramer from Switzerland, so now Felix has also been enrolled 
along with Mary into the Laser Therapy Octogenarians' Society! If any of our other readers would like to have their names mentioned and join the happy band of LTOS members, please do drop me an email and a photograph. I'll be happy to enroll you! In fact later this month it will be my turn to become a member!! It's inevitable, but all the early 1980s LLLT folk are getting old gracefully (well, a little older), and earlier in the year I had a little pre-celebration for my own $80^{\text {th }}$. Rather than a formal event, I decided to instill some levity into the occasion and instead I threw a Karaoke Party! As you know, Japan is the origin of this world-renowned 'art form'. The term 'karaoke' (in the katakana syllabary, カラオケ) comes from two words, カラ (kara, meaning 'empty'), and the shortened first two syllables oke of the katakana for 'orchestra', オー ケストラ, in other words 'empty (i.e., nonexistent) orchestra'. Here is a pictorial memento from my celebration.

Pictured here in the front row, from the left, are my grandson Kōki, myself, and my wife, Yoshiko. In the back row, from the left, are my eldest son Takafumi, my granddaughter Moeno, Takafumi's wife Shizuka, My daughter Madoka Maruyama, my second son Naoyuki, and Madoka's husband, Youhei Maruyama. A good time was has by all!!

\section{End Notes}

I am really delighted to start my End Notes with an announcement of a happy beginning! I am proud and thrilled to intimate that my first son, Dr Takafumi Ohshiro, has been installed this year as the Medical Director of the Ohshiro Clinic. Over the years, Dr Takafumi has played an increasing role in all aspects of the Clinic, and that includes adding his expertise to the Laser Therapy Editorial Team. I am confident that, under his leadership and steady hands, the Ohshiro Clinic will continue to provide excellent care for our patients, and I wish him every success.

I think I may say that I am one of the moving forces behind ILTA and then WALT, and so I have a bone to pick with the Executive Committee of WALT! I'd like to make our readers aware of a name change as far as
WALT is concerned, if they have not heard about it already. I noticed recently it has been changed from the original and much loved 'World Association for Laser Therapy', to the very awkward mouthful of 'World Association for photobiomoduLation Therapy'!! For the life of me I cannot see what sense there is in this change, as a lover of correct terminology. I do understand that the term 'photobiomodulation' is now the accepted MeSH (Medical Subject Heading) term of the US National Library of Medicine, but why change the full name of WALT to include this term, without changing WALT to WAPT? Sometime, the idiocy of the followers of political correctness makes me laugh. In counterpoint to that, I am happy to point out that the term LLLT, which Calderhead and I first coined in the late 1980s, is now so well-accepted that, if any reader cares to run a PubMed search using 'LLLT' as the search term, over 6,200 hits will be generated! This is not at all bad for a term which critics in the late 1980s told me would never be used.

As this is the last issue for Volume 28, the papers for this issue will join those from the previous 3 issues and go out to the Adjudicator Panel for judging the winners of the Ohshiro-Laser Therapy Awards for best and good papers and the 3 papers for the Ming-Chien Kao Award. If you missed out this year, you'd better get writing for inclusion in next year's candidates.

By the time you read this Editorial, those of you who celebrate Christmas will have (hopefully) recovered and are girding your livers for the New Year festivities, but to all our readers, everywhere, all the members of the Laser Therapy Editorial Team wish you the Jolliest of Holiday Seasons, and the Happiest of New Years for 2020. As our Scots LLLT folk will say on Hogmanay (New Year's Eve), "Lang may yer lum reek (wi' ayebody else's coal!)" Roughly translated it means "Long may your chimney smoke (i.e., may you always have a warm fire burning), but preferably with someone else paying for the fuel!

From my family to your family, wherever you are, may you have the triple blessings of Happiness, Peace and Prosperity in 2020.

Tokyo, December 2019

\section{In Memoriam: Professor Kira Samoilova}

I have some very sad late breaking news for our readers. A dear friend, Alex Fedurin, sent me the sad news from St Petersburg, Russia, via email that his beloved wife, Professor Kira Samoilova, died last month while they were on their way to participate in Laser Florence. She was travelling together with Alex when she suffered a major stroke from which she never recovered. Kira and Alex were another of the medical laser world's Great Love Affairs, and were inseparable. Kira was larger than life, and loved life, science and laser, in that order, and she will be sadly missed. We at Laser Therapy are devastated, and I am sure many of Kira's friends and colleagues who are as yet unaware of her passing, will be equally devastated. A proper tribute will be paid in issue 2 of Volume 29. 